\title{
PENGALAMAN KOMUNIKASI IBU DENGAN BABY BLUES SYNDROME DALAM PARADIGMA NARATIF
}

\author{
Mia Dwianna Widyaningtyas \\ Universitas Sultan Ageng Tirtayasa
}

\begin{abstract}
ABSTRAK
Artikel ini menjelaskan tentang pengalaman perempuan dengan Baby Blues Syndrome. Kehadiran seorang bayi dalam keluarga sejatinya menjadi peristiwa yang membahagiakan, namun ternyata perasaan bahagia tidak serta merta dirasakan oleh si ibu yang melahirkan. Informasi yang tidak tepat mengenai kesehatan mental pasca melahirkan, menjadikan melahirkan sebagai hal yang menyedihkan bagi seorang Ibu. Penelitian ini bertujuan mengonstruksi pengalaman, perasaan, dan makna baby blues. Sehingga dengan mengetahui pengalaman, perasaan, dan pemaknaan mengenai Baby Blues, informasi mengenai kondisi perempuan pasca melahirkan dapat menjadi lebih baik. Penelitian ini dilakukan terhadap delapan perempuan yang mengalami baby blues syndrome pasca melahirkan anak pertama atau anak kedua. Pengumpulan data dilakukan dengan wawancara tidak terstruktur dengan pertanyaan terbuka. Beberapa wawancara dilakukan secara langsung namun sebagian dilakukan dengan melalui telpon. Analisis data menggunakan metode Colaizzi. Hasil penelitian menunjukkan dalam konstruk derajat pertama, terdapat 30 pernyataan penting yang berkaitan dengan pengalaman, perasaan, dan pemaknaan akan baby blues. Pada konstruk derajat kedua, penelitian menghasilkan enam tema besar yang menunjukkan fenomenologi Perempuan dengan Baby Blues.
\end{abstract}

Kata-kata Kunci: Pengalaman, Perempuan, Baby Blues Syndrome, Paradigma Naratif

\section{THE EXPERIENCE OF MOTHER WITH BABY BLUES SYNDROME IN NARATIVE PARADIGM}

\begin{abstract}
This article describes the experience of women with Baby Blues Syndrome. The presence of a baby in the family is actually a happy event, but it turns out that feeling happy is not necessarily felt by the mother who gives birth. Misinformation regarding mental health after childbirth, makes childbirth a sad thing for a mother. This study aims to construct the experiences, feelings, and meanings of the baby blues. So by knowing the experiences, feelings, and meanings about the Baby Blues, information about the condition of women after childbirth can be better. This research was conducted on eight women who experienced the baby blues syndrome after giving birth to their first child or second child. Data collection is done by unstructured interviews with open questions. Some interviews are conducted directly, but some are done by telephone. Data analysis using the Colaizzi method. The results of the study show that in the first degree construct, there are 29 important statements relating to the experience, feelings, and meaning of the baby blues. In the second degree construct, the research produced six major themes which showed the phenomenology of Women with Baby Blues.
\end{abstract}

Keywords: Experience, Women, Baby Blues Syndrome, Narrative Paradigm

Korespondensi: Mia Dwianna Widyaningtyas. Universitas Sultan Ageng Tirtayasa. Jl. Raya Jakarta KM.4. Panancangan, Cipocok Jaya, Kota Serang, Banten 42124. Email: mia.dwiana@untirta.ac.id 


\section{PENDAHULUAN}

Bagi sebuah keluarga mendapatkan seorang bayi biasanya menjadi suatu peristiwa yang membahagiakan. Banyak pula yang menggambarkan bahwa melahirkan merupakan keadaan yang membahagiakan, sehingga tidak ada alasan bagi seorang ibu atau keluarga untuk bersedih atau menderita. Namun, terny/ata perasaan bahagia kerap tidak serta merta dirasakan si ibu yang melahirkan bayi, karena transisi menjadi ibu adalah peristiwa besar dalam hidup yang dapat dicirikan sebagai krisis dengan stres yang signifikan. Ibu harus menyesuaikan dan membiasakan diri untuk suatu cara baru dengan yang diistilahkan Heidegger (1927) sebagai beingin-the-world (Roseth, Binder, \& Malt, 2011). Di masa transisi inilah biasanya timbul sebuah kondisi yang dalam dunia kedokteran diistilahkan sebagai depresi pasca melahirkan. Menurut data Badan Kesehatan Dunia (WHO), Postpartum Depression sendiri mempengaruhi sekitar 13 persen perempuan yang ada di dunia. Di Indonesia, tingkatan depresi pasca-melahirkan mencapai 19.8 persen. $^{1}$

\section{Kondisi pasca melahirkan tersebut} diperparah oleh kenyataan bahwa menjadi Ibu dikelilingi oleh mitos (Dalfen, 2009). Mitos tersebut antara lain mengenai hal-hal yang harus dilakukan untuk menjadi ibu yang baik, tentang bagaimana untuk memastikan anak tumbuh sehat, atau tentang hal-hal material yang dibutuhkan.
Mitos juga berkaitan dengan hal-hal yang harus dipikirkan, dirasakan dan dilakukan oleh seorang ibu agar anaknya sukses dan bahagia(Dalfen, 2009). Dalfen (2009) menjelaskan bahwa mitos tentang depresi juga beragam: ada mitos bahwa orang yang tertekan adalah orang lemah dan malas, bahwa depresi adalah bukan benar-benar penyakit tetapi masalah sikap, dan bahwa harus ada sesuatu yang salah dengan kepribadian ibu jika ibu menderita depresi atau kecemasan.

Kondisi depresi pasca melahirkan ini merupakan masalah serius dalam bidang kesehatan masyarakat karena bila tidak diatasi akan dapat mengakibatkan terganggunya kesehatan mental pada ibu-ibu baru(A. Wittkowski, 2011). Menurut Dalfen (2009) sekitar 15 - $20 \%$ ibu baru mengalami depresi pasca melahirkan dan gangguan kecemasan. Dalfen melihat sampai saat ini, masalah tersebut tidak mendapatkan perhatian intensif dari profesi medis, sedikitnya eksposure dari media dan rendahnya kesadaran sosial akan hal ini. Padahal depresi pasca melahirkan serta gangguan kecemasan dapat mempengaruhi ibu dan juga keluarga di salah satu masa yang paling penting dari kehidupan. Banyak informasi yang salah tentang adanya masalah kesehatan mental pasca melahirkan. Misalnya, Kesalahan informasi yang dapat menghentikan seorang ibu baru menyadari bahwa dia menderita atau mungkin membuat ibu baru takut memberitahu siapa pun tentang perasaannya. Oleh karena itu, sangat

\footnotetext{
${ }^{1}$ https://kumparan.com/@kumparanmom/faktor-depresipada-ibu-pasca-melahirkan-dan-cara-mengatasinya diakses 20 Agustus 2018 pukul 19.30 WIB
} 
penting untuk belajar bagaimana mengenali dan memperlakukan para perempuan pasca melahirkan.

Salah satu bentuk depresi pasca melahirkan yang kerap dialami seorang ibu baru dikenal oleh masyarakat dengan istilah "baby blues" (baby bring feeling blues). Keadaan baby blues, dideskripsikan oleh Pitt (1973) sebagai "fenomena sekilas yang sepele". Gejala umum yang terlihat adalah uraian air mata dan terlalu sensitif, yang biasanya hanya berlangsung beberapa hari. Namun, bisa jadi perasaan tersebut tidak mereda dan bahkan bisa menjadi semakin parah. Baby Blues adalah suatu fenomena umum yang tidak perlu terlalu dikhawatirkan (Dalfen, 2009: 49). Baby bring feeling blues atau Baby Blues Syndrome merupakan sebagian besar pengalaman ibu baru di hari-hari awal setelah mereka membawa pulang bayi mereka. $50 \%$ sampai $80 \%$ ibu baru seringkali merasa sedih, marah, dan kadang-kadang cemas(Dalfen, 2009). Beberapa diantara yang terkena baby blues mungkin akan merasa bereaksi berlebihan terhadap situasi dan lebih mudah menangis. Banyak pula, ibu dengan baby blues mengalami kesulitan tidur dan tidak merasa sangat lapar. Kendati merasa tidak berdaya, perempuan yang memiliki Baby Blues bisa terus merawat bayi mereka dan bahkan untuk diri mereka sendiri.

Gejala baby blues biasanya mulai di hari ketiga pasca melahirkan, pada saat itu air susu ibu mulai ada. Dan merupakan suatu kebetulan, baby blues dibawa oleh perubahan hormonal dramatis: estrogen dan progesteron yang menurun, dan hormon menyusui meningkat. Hal ini juga bisa karena kelelahan dan kenyataan bahwa Anda adalah seorang ibu.

Kadang-kadang perempuan yang mengalami hal itu dan keluarganya tidak dapat mengenali bahwa keadaan seperti itu dapat berkepanjangan dan perasaan tidak adil serta tidak bahagia sebagai hal yang abnormal. Pesan-pesan yang sering digambarkan media adalah bahwa melahirkan adalah pengalaman yang menggembirakan dan ibu tidak memiliki alasan untuk menjadi sengsara. Akibatnya ibu mungkin enggan untuk mencari bantuan atau menolak setiap intervensi yang ditawarkan oleh keluarga dan teman-teman. Dalam beberapa kasus ibu mungkin menolak kondisi mereka dan menjadi ekstrem untuk menutupi gejala-gejala tersebut untuk menghindari dicap 'gila' atau seorang ibu 'buruk'. ${ }^{2}$

Kondisi "memendam" sendiri permasalahan secara tidak langsung dapat memperburuk keadaan, karena seperti apa yang disebutkan oleh Paradigma Naratif dari Fisher (West \& Turner, 2010), manusia pada dasarnya adalah mahluk pencerita. Dengan pertimbanganpertimbangan logika yang dimiliki, manusia akan bercerita kepada manusia lainnya. Manusia pada dasarnya adalah mahluk pencerita (West \& Turner, 2010) dengan pertimbangan-pertimbangan logika yang dimiliki, manusia akan bercerita kepada manusia lainnya. Dalam paradigm naratif, logika narasi dipilih dibandingkan logika tradisional yang digunakan dalam argumentasi. Logika narasi, atau

\footnotetext{
${ }^{2}$ NT 3 January 2006 Vol 102 No 1 www.nursingtimes.net diakses 20 Agustus 2018
} 
logika dari pemikiran logis, menyatakan bahwa orang menilai kfredibilitas pembicara melalui apakah ceritanya runtut (mempunyai kohenrensi) dan terdengar benar (mempunyai ketepatan).

Paradigma Naratif yang dikemukakan Walter Fisher ini meyakini bahwa manusia adalah seorang pencerita dan bahwa pertimbangan akan nilai, emosi, dan estetika menjadi dasar keyakinan dan perilaku manusia. Dengan kata lain, seseorang lebih dapat terbujuk oleh sebuah cerita yang bagus dibandingkan oleh sebuah argumen yang baik. Jadi, Fisher, menurut West dan Turner menegaskan bahwa esensi dari sifat dasar manusia adalah menceritakan kisah.

Dalam perspektif Fisher, narasi mencakup deskripsi verbal atau nonverbal apapun dengan urutan kejadian yang oleh para pendengar diberi makna. Definisi Fisher sangat luas dan pararel dengan apa yang dipikirkan oleh banyak orang sebagai komunikasi itu sendiri. Ide dari Fisher: Semua komunikasi adalah naratif. Ia berargumen bahwa naratif bukan sebuah genre khusus (cerita dibandingkan dengan puisi misalnya), melainkan sebuah bentuk pengaruh sosial. Bahkan, menurut Fisher bahwa semua kehidupan disusun dari ceritacerita atau naratif. Kajian komunikasi juga dipengaruhi oleh minat dalam narasi. John Lucaites dan Celeste Condit (1985) sebagaimana dikutip West dan Turner menyatakan, "keyakinan yang berkembang bahwa naratif mewakili medium universal dari kesadaran manusia."

Fisher memperlihatkan paradigma Naratif sebagai penggabungan logika dan estetika, bahkan menekankan bahwa logika naratif berbeda dari logika dan pemikiran tradisional. Aspek-aspek penting dari asumsi Paradigma Naratif adalah bahwa mereka bertolak belakang dengan paradigma dunia rasional.

Dengan dasar ini, bahwa ketika seorang ibu yang baru saja melahirkan tidak bercerita mengenai masalah yang dihadapinya, diduga dapat menambah tingkat stress si ibu. Oleh karena itu perlu dilakukan penelitian mengenai pengalaman perempuan pasca melahirkan dengan baby blues syndrome dalam perspektif ilmu komunikasi. Dengan melakukan penelitian mengenai pengalaman ibu dengan baby blues, dapat lebih memahami mengenai kondisi mereka dan dapat mengantisipasi atau mengambil upaya pemecahan masalah.

Penelitian mengenai pengalaman dengan baby blues atau kondisi depresi pasca melahirkan, telah dilakukan oleh beberapa professional dan akademisi, khususnya yang bergerak ia bidang nursing dan psikologi. Namun, penelitian yang secara khusus membahas mengenai pengalaman ibu dengan baby blues pasca melahirkan dan ditinjau dari perspektif komunikasi, belum penulis temukan. Kendati demikian, terdapat penelitian yang membahas pengalaman ibu pasca melahirkan dilihat dari sudut pandang budaya. Penelitian tersebut telah dimuat di beberapa jurnal. Salah satunya adalah penelitian dari Sally, dkk (Sally Wai-chi Chan, 2009). Penelitian yang dilakukan Sally dkk ini merupakan studi komparasi yang memperbandingkan dua perempuan dari bangsa yang berbeda-yakni Cina dan Australia-ketika masing-masing mengalami kondisi depresi pasca 
melahirkan. Sally melakukan studi pada 35 perempuan Cina dan 12 perempuan Australia yang didiagnosa mengalami depresi pasca melahirkan mendapati bahwa perempuan di dua kelompok tersebut merasakan kesedihan,ketakutan, dan kecemasan. yang sesuai dengan pola perasaan depresi. Kedua kelompok perempuan juga menyatakan keinginan untuk mendapatkan kembali kendali atas kehidupan mereka. Perbedaan budaya dan penanganan kesehatan dipengaruhi makna bahwa perempuan ditugaskan sesuai dengan pengalaman mereka dan perilaku mereka mencari bantuan.

Penelitian sejenis dilakukan oleh Roseth dan Williamso (Roseth et al., 2011). Mereka meneliti empat perempuan yang didiagnosa mengalami depresi yang parah. Dalam artikel mereka yang berjudul" Two Ways of Living through Postpartum Depression" Roseth den Williamso menyebukan bahwa penelitian ini merupakan bagian dari studi fenomenologis yang lebih dalam dengan menjelajahi makna depresi melalui pengalaman perempuan. Semua ibu baru di setiap negara bagian Norwegia rutin datang ke dalam kontak dengan klinik kesehatan lokal di dua minggu pasca melahirkan. Hasil penelitian Roseth dalam konstruk derajat 1 yakni: para ibu merasa cemas, rentan dan tak berdaya di dunia yang berbahaya dan obstruktif. kecemasan dan ketidakberdayaan dalam menghadapi dunia ini terlihat melalui kegelisahan dan berat badan mereka. Mereka mengalami aktivitas sehari-hari dan merawat bayi mereka sebagai hal yang sulit dan mengakibatkan stres. Dalam konstruk derajat
2, pengalaman ibu bahwa persepsi, pikiran, dan emosi nya telah menghilangkan kualitas hidupnya. Berbeda dengan penelitian-penelitian sejenis yang telah penulis paparkan, penelitian dilakukan untuk melihat pengalaman komunikasi para perempuan yang mengalami syndrome ini dan membahas dalam paradigma naratifAdapun tujuan dari penelitian ini adalah untuk mendeskripsikan pengalaman dan perasaan perempuan yang pernah mengalami Baby Blues Syndrome serta pemaknaan mereka atas syndrome ini.

\section{METODE PENELITIAN}

Penelitian ini merupakan studi untuk menggali pengalaman dan makna dari ibu-ibu yang mengalami baby blues dari perspektif ilmu komunikasi Studi fenomenologi mendeskripsikan pemaknaan umum dari sejumlah individu terhadap pengalaman hidup mereka terkait dengan konsep atau fenomena. Studi fenomenologi yang dirintis oleh Edmund Husserl adalah ilmu mengenai sesuatu yang tampak (fenomenon). Dengan demikian setiap penelitian atau setiap karya yang membahas cara penampakan dari apa saja merupakan fenomenologi. Studi fenomenologi mendeskripsikan pemaknaan umum dari sejumlah individu terhadap pengalaman hidup mereka terkait dengan konsep atau fenomena. Para fenomenolog memfokuskan untuk mendeskripsikan apa yang sama/umum dari semua partisipan ketika mereka mengalami fenomena (J. W. Creswell, 2014: 105). Fenomenologi menjelaskan struktur kesadaran dalam pengalaman manusia. Pendekatan fenomenologi berupaya membiarkan realitas 
mengungkapkan dirinya sendiri secara alami. Melalui "pertanyaan pancingan", subjek penelitian dibiarkan menceritakan segala macam dimensi pengalamannya berkaitan dengan sebuah fenomena/peristiwa. Studi fenomenologi berasumsi bahwa setiap individu mengalami suatu fenomena dengan segenap kesadarannya. Dengan kata lain, studi fenomenologi bertujuan untuk menggali kesadaran terdalam para subjek mengenai pengalamannya dalam suatu peristiwa (Creswell, 1998)

Pengalaman manusia ini menurut Moustakas sebagaimana dibahas J.W.Cresswell (2014: 105) dapat berupa fenomena, misalnya insomnia, kesendirian, kemarahan, dukacita atau pengalaman operasi. Asumsi filosofis studi fenomenologi berpijak pada sebagian landasan yang sama: studi tentang pengalaman hidup dari person, pandangan bahwa pengalaman bersifat sadar, dan pengembangan deskripsi tentang esensi dari pengalaman ini, bukan penjelasan, atau analisis.

$$
\text { Peneliti menggunakan metode }
$$
fenomenologi dalam penelitian ini dengan beberapa pertimbangan: (1) fokus penelitian ini adalah mengenai realitas yang tampak melalui pengalaman atau kesadaran. Dalam hal ini akan menekankan pada penggambaran (deskripsi); (2) Peneliti lebih bisa mengeksplorasi fenomena penelitian; (3) Peneliti dapat berinteraksi langsung dengan partisipan

Para fenomenolog memfokuskan untuk mendeskripsikan apa yang sama/umum dari semua partisipan ketika mereka mengalami fenomena.(J.
W. Creswell, 2014). Untuk mendapatkan pengalaman sebenarnya mengenai baby blues, peneliti melakukan wawancara kepada 8 orang perempuan (ibu) yang mengalami sindrom tersebut. Sebagian besar partisipan, merupakan perempuan yang baru pertama kali melahirkan. Pemilihan partisipan penelitian dilakukan dengan purposive sampling dengan ketentuan bahwa partisipan secara sadar pernah mengalami Baby Blues. Peneliti melakukan wawancara secara langsung dengan pola pertanyaan tidak terstruktur. Dalam fenomenologi, peneliti mengesampingkan pengetahuan dan pengalaman masa lalu untuk memahami fenomena pada level yang lebih (J. W. Creswell, 2014)

Untuk menganalisis data, peneliti menggunakan prosedur dari Colaizzi yang diilustrasikan Moustakas (J. W. Creswell, 2014) sebagai berikut: mengidentifikasikan fenomena yang hendak dipelajari, mengurung pengalaman sendiri, dan mengmpulkan data dari beberapa orang yang mengalami fenomena tersebut. Penulis kemudian menganalisis data tersebut dengan mereduksi informasi menjadi pernyataan atau kutipan penting dan memadukan pernyataan tersebut menjadi tema.

Pengecekan keabsahan data perlu dilakukan untuk memperoleh data yang dipercaya. Pengecekan keabsahan data dalam penelitian ini akan dilakukan dengan teknik yang dijelaskan Dukes (J. W. Creswell, 2014), yaitu (1) konfirmasi kepada beberapa peneliti lain, terutama mereka yang meneliti pola-pola yang mirip, (2) verifikasi data oleh pembaca naskah hasil penelitian, 
terutama dalam hal penjelasan logis dan cocok tidaknya dengan pembaca naskah, (3) analisis rasional dari pengenalan spontan yakni dengan menjawab pertanyaan berikut ini yaitu apakah pola penjelasan cocok dan logis? dan apakah bisa digunakan untuk pola penjelasan yang lain?, (4) peneliti menggolongkan data di bawah data yang sama/cocok

Dalam penelitian mengenai "Fenomenologi Ibu dengan Baby Blues" ini, paradigma naratif menjadi pisau analisis untuk membahas mengenai upaya -upaya mengatasi baby blues. Seperti yang dikemukakan di awal, bahwa manusia pada dasarnya makhluk pencerita, sehingga dalam kondisi bagaimana pun ia membutuhkan orang lain untuk bercerita

\section{HASIL DAN PEMBAHASAN}

Dari hasil wawancara mendalam yang dilakukan kepada 8 informan, peneliti mendapatkan sekira 29 pernyataan penting yang terkait dengan pertanyaan penelitian. Peneliti kemudian menyarikan pernyataan-pernyataan penting dari hasil wawancara tersebut sebagai unitunit makna, dan menyisihkan pernyataan yang berulang. Selanjut dicari formulasi makna dari pernyataan-pernyataan pening tersebut. Peneliti kemudian mengorganisasikan makna-makna ke dalam kelompok-kelompok tema umum. Berikut tabel mengenai pernyataan penting dari pengalaman ibu dengan baby blues, pernyataan penting dari perasaan ibu dengan baby blues dan tema yang dihasilkan.
Tabel 1 Pernyataan Penting berkaitan dengan Pengalaman Baby Blues

1. Masa-masa terkelam terjadi selama 40 hari setelah melahirkan

2. Dihakimi sebagai ibu yang tidak bisa mengurus anak

3. Tidak bisa tidur

4. Tidak ada nafsu makan

5. Seperti mendapat beban berat

6. Menangis tanpa sebab

7. Kurang pengetahuan

8. Bertengkar dengan suami atau mertua

9. Memukul bayi

10. Mendapat dukungan suami

11. Mendapat bantuan dari orang lain

12. bercerita pada orang lain

13. Berpikiran positif

14. Opini negatif dari yang menengok

Pernyataan-pernyataan tersebut kemudian dikaji kembali. Untuk yang sama Setelah dilakukan penyaringan, maka didapat 9 deskripsi tekstural yang kemudian disusun makna rumusannya, yang dijelaskan pada tabel 2.

\section{Tabel 2. Pernyataan-Pernyataan Penting dari Pengalaman Ibu dengan Baby Blues dan Makna Rumusan}

\begin{tabular}{|l|l|l|}
\hline & $\begin{array}{l}\text { Pernyataan } \\
\text { Penting }\end{array}$ & $\begin{array}{l}\text { Makna Rumusan } \\
\text { berantakan dan } \\
\text { bahkan tidak bisa } \\
\text { tidur sama sekali. }\end{array}$ \\
\hline 2. & $\begin{array}{l}\text { Baby blues } \\
\text { merupakah } \\
\text { realitas yang } \\
\text { membuat } \\
\text { perubahan pola } \\
\text { hidup ibu } \\
\text { makan }\end{array}$ & $\begin{array}{l}\text { Baby blues } \\
\text { menjadikan } \\
\text { seorang ibu tidak } \\
\text { ingin makan }\end{array}$ \\
\hline 3. & $\begin{array}{l}\text { Sering menangis } \\
\text { tanpa sebab }\end{array}$ & $\begin{array}{l}\text { Ibu } \\
\text { mengalami baby } \\
\text { blues emosinya } \\
\text { tidak stabil }\end{array}$ \\
\hline 4. & $\begin{array}{l}\text { Dihakimi sebagai } \\
\text { ibu yang tidak }\end{array}$ & $\begin{array}{l}\text { Stigma ibu yang } \\
\text { tidak trampil }\end{array}$ \\
\hline
\end{tabular}




\begin{tabular}{|c|c|c|}
\hline & $\begin{array}{ll}\text { bisa mengurus } \\
\text { anak }\end{array}$ & \\
\hline 5 & $\begin{array}{l}\text { Bertengkar } \\
\text { dengan suami } \\
\text { atau anggota } \\
\text { keluarga lain }\end{array}$ & Muncul konflik \\
\hline 6 & $\begin{array}{lr}\text { Memukul anak } \\
\text { karena } \\
\text { berhenti menangis }\end{array}$ & $\begin{array}{l}\text { Tidak dapat } \\
\text { menyalurkan } \\
\text { emosi }\end{array}$ \\
\hline 7 & $\begin{array}{l}\text { Menjadi masa- } \\
\text { masa kelam yang } \\
\text { harus dihadapi }\end{array}$ & $\begin{array}{l}\text { Bayangan } \\
\text { kegagalan muncul } \\
\text { dalam kurun } \\
\text { waktu serangan } \\
\text { baby blues }\end{array}$ \\
\hline 8 & $\begin{array}{ll}\text { Mendapat } & \\
\text { dukungan } & \text { dari } \\
\text { suami } & \text { atau } \\
\text { keluarga } & \end{array}$ & $\begin{array}{l}\text { Baby blues mudah } \\
\text { diatasi jika ada } \\
\text { support dari orang } \\
\text { lain }\end{array}$ \\
\hline 9 & Berpikiran positif & $\begin{array}{l}\text { Kemampuan } \\
\text { mengatasi } \\
\text { permasalahan }\end{array}$ \\
\hline
\end{tabular}

Selanjutnya, tabel 3 menunjukkan pengalaman sadar yang berkaitan dengan perasaan pada ibu dengan baby blues syndrome.

Tabel 3. Perasaan Ibu dengan Baby Blues Syndrome

1. Ibu yang tidak berguna
2. Sedih
3. Kecewa
4. Lekas marah
5. Sendirian
6. Capek, stress
7. Cemas
8. Khawatir tidak dapat membesarkan
9. Tidak percaya diri
10. Tidak bebas lagi
11. Rindu pada suami
12. Tersudut
13. Semangat
14. Yakin bisa mengatasi
15. Senang melihat wajah bayi

Pernyataan-pernyataan tersebut kemudian dikaji kembali. Untuk yang sama Setelah dilakukan penyaringan, maka didapat 13 deskripsi tekstural yang kemudian disusun menjadi makna rumusan, yang dijelaskan pada tabel 4.

\section{Tabel 4. Pernyataan-pernyataan penting mengenai perasaan ibu dengan baby blues}

\begin{tabular}{|c|c|c|}
\hline No & $\begin{array}{l}\text { Pernyataan } \\
\text { Penting }\end{array}$ & $\begin{array}{l}\text { Makna yang } \\
\text { dirumuskan }\end{array}$ \\
\hline 1. & Sedih & $\begin{array}{l}\text { Turunnya emosi ibu } \\
\text { dengan baby blues }\end{array}$ \\
\hline 2 & Kecewa & $\begin{array}{l}\text { Ketidakmampuan } \\
\text { mengatasi masalah }\end{array}$ \\
\hline 3 & Lekas marah & $\begin{array}{l}\text { Emosi yang tidak } \\
\text { stabil }\end{array}$ \\
\hline 4 & Cemas & Perubahan kehidupan \\
\hline 5 & $\begin{array}{l}\text { Khawatir tidak } \\
\text { bisa membesarkan } \\
\text { anak }\end{array}$ & pesimistis \\
\hline 6 & $\begin{array}{l}\text { Khawatir akan } \\
\text { nasib anak kelak }\end{array}$ & $\begin{array}{l}\text { Bayangan buruk masa } \\
\text { depan }\end{array}$ \\
\hline 7 & Tidak percaya diri & $\begin{array}{l}\text { kekurangan } \\
\text { pengetahuan dalam } \\
\text { mengurus bayi }\end{array}$ \\
\hline 8 & $\begin{array}{l}\text { Merasa sendiri/ } \\
\text { terasing }\end{array}$ & $\begin{array}{l}\text { Tidak ada perhatian } \\
\text { dari orang lain }\end{array}$ \\
\hline 9 & $\begin{array}{l}\text { Merasa tidak } \\
\text { bebas lagi }\end{array}$ & Perubahan peran \\
\hline 10 & Semangat & $\begin{array}{l}\text { Kekuatan mengatasi } \\
\text { masalah }\end{array}$ \\
\hline 11 & $\begin{array}{l}\text { Yakin bisa } \\
\text { mengatasi }\end{array}$ & optimis \\
\hline 12 & Capek, Stress & $\begin{array}{l}\text { Turunnya emosi ibu } \\
\text { dengan baby blues }\end{array}$ \\
\hline 13 & Rindu pada suami & $\begin{array}{l}\text { kebutuhan akan } \\
\text { kehadiran orang lain }\end{array}$ \\
\hline 14 & $\begin{array}{l}\text { Senang melihat } \\
\text { bayi }\end{array}$ & $\begin{array}{l}\text { Kekuatan mengatasi } \\
\text { masalah }\end{array}$ \\
\hline
\end{tabular}

Deskripsi struktural pengalaman dan perasaan Ibu dengan baby blues syndrome ini kemudian dianalisis, sehingga menghasilkan tematema yang berkaitan dengan pemaknaan mengenai 
baby blues syndrome. Adapun makna-makna yang terbentuk disajikan pada tabel 5 .

\section{Tabel 5. Makna yang terbentuk berdasarkan pengalaman dan perasaan dari Ibu dengan Baby Blues}

\begin{tabular}{|l|l|l|l|l|l|}
\hline \multicolumn{5}{|l|}{ Pemaknaan Ibu atas Baby Blues Syndrome } \\
\hline $\begin{array}{l}\text { Perub } \\
\text { ahan }\end{array}$ & $\begin{array}{l}\text { Kon } \\
\text { flik }\end{array}$ & $\begin{array}{l}\text { Dukun } \\
\text { gan }\end{array}$ & $\begin{array}{l}\text { Em } \\
\text { osi }\end{array}$ & $\begin{array}{l}\text { Peruba } \\
\text { hana }\end{array}$ & $\begin{array}{l}\text { Optim } \\
\text { istik }\end{array}$ \\
Pola & & dari & yan & Peran & \\
hidup & & Lingku & g & & \\
dan & & ngan & tida & & \\
Perila & & & k & & \\
ku & & & stab & & \\
& & & il & & \\
\hline
\end{tabular}

Deskripsi dari pemaknaan Ibu atas baby blues syndrome adalah sebagai berikut (1) perubahan Perilaku dan Pola Hidup merupakan perubahan yang terjadi di dalam diri ibu yang mengalami baby blues pasca melahirkan, dengan bentuk-bentuk: pola tidur yang berantakan, kehilangan nafsu makan, dan sering menangis tanpa sebab; (2) konflik merupakan hal yang dialami oleh ibu dengan baby blues, karena benturan-benturan ketika berinteraksi dengan lingkungan sekitar, (3) dukungan lingkungan merupakan pengalaman-penglaman yang diperoleh ibu dengan baby blues ketika berinteraksi dengan lingkungannya, yakni ketika mendapat dukungan dari suami atau keluarga, bertemu dengan orang lain yang bercerita hal-hal yang mengembirakan, dan pikiran - pikiran positif dari dalam maupun luar diri, (4) emosi yang berlebihan merupakan perasaan-perasaanl dari diri ibu dengan baby blues dan muncul dalam bentuk tertentu seperti sedih, cemas, stress, kecewa, dan lain-lain, sebagai akibat mitos, anggapan-anggapan masyarakat, lingkungan sekitar serta hormon pasca melahirkan, (5) perubahan peran merupakan perasaan-perasaan ibu dengan baby blues yang muncul karena perubahan peran pasca mendapatkan seorang bayi. Kesadaran adanya tuntutan sebagai seorang ibu mnimbulkan perasaan tidak bebas lagi, terasing, dan tidak percaya diri, dan (6) optimistik merupakan perasaan yang muncul karena dorongan-dorongan dari dalam dan dari luar untuk dapat mengatasi masalah baby blues ini.

Penelitian ini merupakan studi untuk menggali pengalaman dan makna dari ibu-ibu yang mengalami baby blues dari perspektif ilmu komunikasi. Berkaitan dengan hal tersebut, penelitian ini menggunakan dua teori sebagai pisau analisis, yakni paradigma naratif dan teori interaksi simbolik.

Baby blues merupakan suatu kondisi yang dapat dialami para perempuan pasca melahirkan, dengan tidak memandang profesi, ras, atau bahkan usia. Kendati seorang perempuan telah mempunyai pengetahuan mengenai baby blues, namun perasaan-perasaan yang muncul akibat baby blues ini tidak dapat dihindari. Kalaupun si ibu "siap" itu hanya mengurangi tingkat "stress' akibat baby blues ini. Dalam studi ini, para ibu dengan pengalaman baby blues hampir seluruhnya mengalami perubahan pola hidup dan perilaku, ketidakstabilan emosi. Sejalan dengan penelitian Sally, dkk yang menjelaskan bahwa perempuan dalam hal ini bangsa Cina dan Australia yang merasakan kesedihan, ketakutan, dan kecemasan. yang sesuai dengan pola perasaan depresi pasca melahirkan. 
Perasaan-perasaan tersebut muncul karena kesadaran akan perubahan peran menjadi ibu. Para ibu ini memaknai baby blues ini sebagai sebuah hal yang wajar dan memang harus dialami oleh seorang ibu . Seperti kata AA:

"Nah, inilah mungkin yang disebut baby blues syndrome seperti yang pernah saya baca dalam teori." (Kutipan wawancara dengan AA, Juli 2018)

Reaksi-reaksi yang muncul dari seorang ibu akibat baby blues ini juga tidak lepas dari pengaruh unsur lingkungan, antara lain mitos-mitos yang terbentuk di masyarakat. Seperti salah satu partisipan yang mengatakan :

"Di tradisi Jawa, sebelum selapan ibu yang habis melahirkan dilarang tidur siang, karena bisa bikin darah putih naik, dan bikin si ibu yg abis melahirkan ini pucat"

Seperti yang dijelaskan oleh Mead dalam Mulyana (2013) bahwa makna adalah produk interaksi sosial, karena itu makna tidak melekat pada obyek, melainkan dinegosiasikan melalui penggunaan Bahasa. Negosiasi itu dimungkinkan karena manusia mampu menamai segala sesuatu , bukan hanya objek fisik, tindakan atau peristiwa, namun juga gagasan yang abstrak. Akan tetapi, nama atau symbol yang digunakan untuk menandai objek, tindakan, peristiwa, atau gagasan itu bersifat arbitrer (sembarang). Mulyana (2013) menjelaskan bahwa interaksionisme simbolik didasarkan premis-premis: pertama individu merespons suatu situasi simbolik. Mereka merespons lingkungan termasuk objek fisik (benda) dan objek sosial (perilaku manusia) berdasarkan makna yang dikandung komponen-komponen lingkungan tersebut bagi mereka. Ketika mereka menghadapi suatu situasi, respons mereka tidak bersifat mekanis, tidak pula ditentukan oleh faktor-faktor eksternal; individulah yang dipandang aktif untuk menentukan lingkungan mereka sendiri. Premis kedua interaksionisme simbolik seperti dijelaskan oleh Mulyana bahwa makna adalah produk interaksi sosial, karena itu makna tidak melekat pada obyek, melainkan dinegosiasikan melalui penggunaan bahasa. Negosiasi itu dimungkinkan karena manusia mampu menamai segala sesuatu , bukan hanya objek fisik, tindakan atau peristiwa, namun juga gagasan yang abstrak. Melalui penggunaan symbol itulah manusia dapat berbagi pengalaman dan pengetahuan tentang dunia.

Salah satu respon awal ketika seorang ibu menyadari dia mengalami baby blues adalah mulai mencari cara untuk mengatasi hal ini. Beberapa responden menyadari bahwa cara untuk mengatasi masalah ini adalah dengan berkonsultasi dengan ahli atau berbicara kepada orang terdekat mengenai perasaan-perasaan yang muncul akibat baby blues ini. Sebagian responden mengatakan hal tersebut. Salah satunya menyatakan sebagai berikut:

"Jangan pendam sendiri. Bicara dengan suami, orang tua, adik ataupun sahabat bisa mengurangi tingkat keparahan baby blues. Terutama kepada suami" (Hasil wawancara dengan RS , Juli 2018)

Hal ini menegasan bahwa esensi dari sifat dasar manusia adalah menceritakan kisah. Dalam perspektif Fisher, narasi (narration) mencakup deskripsi verbal atau nonverbal apapun dengan 
urutan kejadian yang oleh para pendengar diberi makna. Hal ini dapat dihubungkan dengan esensi manusia sebagai mahluk pencerita seperti asumsi Fisher dari Manusia pada dasarnya adalah mahluk pencerita (West \& Turner, 2010) dengan pertimbangan-pertimbangan logika yang dimiliki, manusia akan bercerita kepada manusia lainnya.

Dalam paradigm naratif, logika narasi dipilih dibandingkan logika tradisional yang digunakan dalam argumentasi. Logika narasi, atau logika dari pemikiran logis, menyatakan bahwa orang menilai kfredibilitas pembicara melalui apakah ceritanya runtut (mempunyai kohenrensi) dan terdengar benar (mempunyai ketepatan) (West \& Turner, 2010)

Paradigma naratif yang dikemukakan Walter Fisher ini meyakini bahwa manusia adalah seorang pencerita dan bahwa pertimbangan akan nilai, emosi, dan estetika menjadi dasar keyakinan dan perilaku manusia. Dengan kata lain, seseorang lebih dapat terbujuk oleh sebuah cerita yang bagus dibandingkan oleh sebuah argumen yang baik. Jadi, Fisher, menurut West dan Turner menegaskan bahwa esensi dari sifat dasar manusia adalah menceritakan kisah.

Dalam perspektif Fisher, narasi mencakup deskripsi verbal atau nonverbal apapun dengan urutan kejadian yang oleh para pendengar diberi makna. Definisi Fisher sangat luas dan pararel dengan apa yang dipikirkan oleh banyak orang sebagai komunikasi itu sendiri. Ide dari Fisher: Semua komunikasi adalah naratif. Ia berargumen bahwa naratif bukan sebuah genre khusus (cerita dibandingkan dengan puisi misalnya), melainkan sebuah bentuk pengaruh sosial. Bahkan, menurut Fisher bahwa semua kehidupan disusun dari ceritacerita atau naratif.

Kajian komunikasi juga dipengaruhi oleh minat dalam narasi. John Lucaites dan Celeste Condit (1985) sebagaimana dikutip West dan Turner menyatakan, "keyakinan yang berkembang bahwa naratif mewakili medium universal dari kesadaran manusia."

Fisher memperlihatkan paradigma Naratif sebagai penggabungan logika dan estetika, bahkan menekankan bahwa logika naratif berbeda dari logika dan pemikiran tradisional. Aspek-aspek penting dari asumsi Paradigma Naratif adalah bahwa mereka bertolak belakang dengan paradigma dunia rasional.

Alternatif pemecahan masalah dengan bercerita, merupakan salah satu esensi dari tujuan komunikasi.Selain berbicara dengan orang terdekat, bertemu dengan orang lain dalam kondisi yang berbeda dapat menjadi alternatif mengurangi perasaan buruk yang muncul akibat baby blues syndrome. Seperti disampaikan IPS, salah satu partisipan:

Bertemu dengan banyak orang. Bertemu dengan banyak orang membuat fikiran kita tidak akan berfokus pada diri kita sendiri. Akan banyak informasi, Canda yang menghibur, juga tuntutan untuk selalu tersenyum, yang mengurangi baby blues yang kita rasakan. (Hasil wawancara dengan IPS , Juli 2018)

Dengan demikian, faktor komunikasi membantu mengatasi permasalahan-permasalahan Ibu yang mengalami baby blues. 


\section{SIMPULAN}

Baby blues merupakan pengalaman sadar para perempuan pasca melahirkan yang disebabkan faktor hormonal dan perubahan lingkungan keluarga akibat adanya anggota baru. Dukungan lingkungan dalam hal ini anggota keluarga yang dapat menjadi pendengar dan memahami perempuan dengan baby blues, menjadikan baby blues sebagai pengalaman yang wajar dialami oleh Ibu Pasca melahirkan. Namun, bila tidak diatasi dapat menjadi sebuah pengalaman buruk yang menimbulkan depresi.

Perempuan yang mengalami baby blues sering merasakan kesedihan, kecemasan, perasaan tidak dihargai, serta sering memendam perasaan karena kekhawatiran akan stigma-stigma dari orang sekitar. Padahal memendam perasaan dapat memperparah kondisi perempuan pasca melahirkan. Manusia pada dasarnya adalah makhluk pencerita, sehingga dalam kondisi bagaimana pun ia membutuhkan orang lain untuk bercerita.

Penelitian mengenai perempuan dengan baby blues syndrome ini menghasilkan konstruksi makna mengenai baby blues syndrome. Maknamakna yang muncul dari perempuan dengan baby blues syndrome ini dipengaruhi oleh lingkungan sosial dan hasil komunikasi dengan orang-orang terdekat. Mitos yang mengelilingi perempuan pasca melahirkan membuat pemaknaan yang lain mengenai baby blues ini.

\section{DAFTAR PUSTAKA}

A. Wittkowski, A. Z., S. Glendenningc and J.R.E. Fox. (2011). The experience of postnatal depression in South Asian mothers. Journal of Reproductive and Infant Psychology Vol. 29, No. 5, , 480-492.

Creswell. (1998). Qualitative Inquiry: Choosing Among Five Tradtions. Sage Publications. Sage Publications.

Creswell, J. W. (2014). Penelitian Kualitatif \& Desain Riset Memilih diantara Lima Pendekatan edisi 3. Yogyakarta: Pustaka Pelajar.

Dalfen, A. (2009). When Baby Brings the Blues Solutions for Postpartum Depresssion. Canada: John Wiley \& Sons Canada, Ltd.

Mulyana, D. (2013). Metodologi Penelitian Kualitatif Paradigma Baru Ilmu Komunikasi dan Ilmu Sosial Bandung Remaja Rosdakarya.

Roseth, I., Binder, P. E., \& Malt, U. F. (2011). Two ways of living through postpartum depression. J. Phenomenol. Psychol. Journal of Phenomenological Psychology, 42(2), 174-194.

Sally Wai-chi Chan, R., BSc, MSc, PhD, Victoria Williamson, RN, BA Hons, MSocSc, PhD,. (2009). A Comparative Study of the Experiences of a Group of Hong Kong Chinese and Australian Women Diagnosed With Postnatal Depression. Perspectives in Psychiatric Care Vol. 45, No. 2, April 2009, $108-118$.

West, R., \& Turner, L. H. (2010). Introducing Communication Theory, Analysis and Application. New York: McGraw Hill Education. 